Indonesian Journal of EFL and Linguistics

Vol. 3 No. 2, 2018

eISSN: 2503-4197, pISSN: 2527-5070

www. indonesian-efl-journal.org

\title{
Understanding the Choices of Terms of Address: A Sociolinguistic Study of Malay Cultural Practices
}

\author{
Nor Shahila Mansor*, Normaliza Abd Rahim, Roslina Mamat, Hazlina Abdul Halim \\ Universiti Putra Malaysia \\ Corresponding author*:nsm@upm.edu.my
}

\begin{abstract}
:
This paper investigates the choices of second person terms of address in the Malay culture. It examines the different patterns of address terms used in a range of communicative situations by interlocutors coming from diverse social backgrounds. The data for this study was obtained from two Malay dramas Ijab \& Qabul (The solemnization of marriage) and Tiga Hari Menanti Mati (Three Days Until Death). These dramas were selected because they reflect in the usage of terms of address in an authentic social context of the Malay culture and represent various interpersonal relationships in a range of situations. This is a descriptive study with a qualitative approach. Forty-eight different second person terms of address were recorded and analysed in specific contexts based on the framework for classifying address terms established by Kroger, Wood and Kim (1984). The findings suggest that sociolinguistic elements such as interlocutors, contexts, determinants of interpersonal relationship, and intentions were determining factors influencing the choice of second person terms of address in the Malay culture. These findings have implications on the understanding of current trends in choosing the terms of address among Malay speakers
\end{abstract}

Keywords: second person, address forms, Malay language, interpersonal relationship, cultural practice 


\section{INTRODUCTION}

Numerous studies on personal address terms have been conducted by researchers around the globe. Among other definitions, address forms are identified as words or expressions used by a speaker to refer to the addressee during verbal interactions that also conveys social information (Parkinson, 1985). In social relationships, the status and intimacy between interlocutors determine the choice of address forms, however, in certain cultures, the selection of address forms is also connected to the culture's rules of politeness. In the English culture, the most common forms of address are first name and title + last name (Brown and Ford, 1961). Meanwhile, in the Malay culture, where politeness is strictly observed, the use of titles or honorifics are often customary to indicate the social status of particular individuals (Hei, David, Kia and Soo, 2011; Gan, David and Dumanig, 2015). This is consistent with Brown and Levinson's (1987) politeness theory which classifies address terms, among other elements, as part of the politeness strategies. By using specific terms of address, the speaker indirectly establishes the relative power and distance between the speaker and the person being spoken to (Wood and Kroger, 1991).

The main objective of this study is twofold. This study aims to first investigate the current trends in the usage of address terms among Malay speakers across a range of situations and between diverse interlocutors. This study then aims to examine whether the alleged universality of Brown's invariant norm of address (1965) extends to the Malay language. It is however, fundamental to clarify that the phrase "terms of address" in this paper only refers to vocatives that consists of terms of direct address to call a person (Chao, 1956), such as names, like Mary, titles without a name, like Sir and Doctor, or any expression used to address a person, like hey and man (Qin, 2008).

In a time where intercultural interaction is becoming an essential part of communication, there is a crucial need to overcome the prevailing language barrier within the society and this has resulted in the push to cultivate and enhance linguistic competence. In response to this matter, this study pursues to contribute to the body of knowledge by attempting to comprehensively explain the present-day usage of Malay address terms and determining the social factors that regulate the selection of these terms.

\section{PREVIOUS STUDIES ON TERMS OF ADDRESS}

In general, the usage of terms of address vary from one culture to another. In English and European cultures for example, the use of first name and title (i.e John, Sir/Madam) are considered common practice in showing respect and expressing politeness toward the hearer. Nevertheless, in Asian countries such as Malaysia, China and the Philippines, politeness and respect between interlocutors are indicated through the usage of title and kinship terms (Gaudart, 2009).

In a study of Chinese address system that describes in detail the terms of address and its uses in various interpersonal relationships conducted by Chao (1956), it was revealed that the Chinese language has a complicated kinship system compared to other languages. However, a similar condition can be observed in the Malay 
language. The complex principle in naming and addressing family members and other relatives is as follows:

The complex principle in naming and addressing

\begin{tabular}{|l|l|l|}
\hline Family members & Birth order & Kinship terms \\
\hline sibling - brother & first / eldest & abang long / along \\
\cline { 2 - 3 } & middle / second oldest & abang ngah / angah \\
\cline { 2 - 3 } & last / youngest & abang cik / acik / adik \\
\hline \multirow{5}{*}{ sibling - sister } & first / eldest & kaklong / along \\
\cline { 2 - 3 } & middle / second oldest & kakngah / angah \\
\cline { 2 - 3 } & last / youngest & kakcik / acik / adik \\
\hline uncle & parent's eldest brother & pak long \\
\cline { 2 - 3 } & $\begin{array}{l}\text { parent's second oldest } \\
\text { brother }\end{array}$ & pak ngah \\
\cline { 2 - 3 } & parent's youngest brother & pak su / pak busu \\
\cline { 2 - 3 } & generic & pakcik \\
\hline aunt & parent's eldest sister & mak long \\
\cline { 2 - 3 } & $\begin{array}{l}\text { parent's second oldest } \\
\text { sister }\end{array}$ & mak ngah \\
\cline { 2 - 3 } & parent's youngest sister & mak su / mak usu \\
\cline { 2 - 3 } & generic & makcik \\
\hline
\end{tabular}

This list shows the kinship terms of two generations: parent's generation and child's generation. For siblings, with the exception of 'adik' (little brother or little sister), gender is indicated and reflected in all of the terms. Among the family members, the children are addressed following their birth order. The eldest is called 'sulung', the second oldest is 'tengah' and the youngest is 'bongsu'. While 'abang' means brother and 'kakak' is sister. The same applies to kinship terms for the parent's generation. The forms 'pak' (father) and 'mak' (mother) followed by an expression indicating the birth order 'sulung', 'tengah' and 'bongsu' are used when addressing uncles and aunts. 'Makcik' and 'pakcik' are generic terms to address elderly individuals perceived as being within the same age range as the speakers' parents including strangers such as an elderly taxi or bus driver. All of these expressions are normally used in a non-formal setting both in written (mostly in literature texts) and spoken form.

According to Gan, David and Dumanig (2015: 52), the use of address terms during interaction plays an important role especially in a society which is socially stratified. The use of address terms not only reflect the social rankings of the respective individuals (Hei, David, Kia and Soo, 2011) but also classify interlocutors into a particular category (Hayakawa, 1978: 16). For instance, as shown in the list in Table 1 , it can be observed that particular expressions such as 'long', 'ngah', 'usu' and 'cik' suggests the number of children and their birth order in a Malay family.

In a study that examined the usage of address forms by Korean, Greek and Chinese speakers, Kroger, Wood and Kim (1984) coded the data collected from the 
participants through their dyadic address exchanges into three quantitative indices that assess the degrees of reciprocity, solidarity, and inequality. The findings suggested the universality of the rules of address in the studied languages, including in Korean and Chinese. The study proposed that there were no significant differences in the use of address forms between Korean speakers living in Korea and those living in Canada.

The results of Dittrich, Johansen and Kulinskaya's (2011) study however, contrasted Kroger's et al.'s (2011) findings. In their study, Dittrich et al. (2011) compared the norms and situational rules of address among English and Norwegian speakers in their respective countries. The statistical approach used in the study allowed the researchers to make direct comparisons of the linguistic patterns between observed and expected terms of address in both languages. The results showed that the usage of address terms between English and Norwegian speakers differed and therefore does not support the assumption of universality the invariant norm of address.

Previous studies have also reported gender as a factor that influences the use of address terms. Normala Othman (2006) examined the trends in the usage of pronouns among Malay speakers based on three sociolinguistic variables: gender, age and formality. The data was collected via questionnaires, taped conversations and random observations among participants in urban areas particularly Kuala Lumpur. The results showed that the use of address terms differed between men and women. Educated and urbanized women tend to use more English pronouns in their interactions with colleagues and friends while Malay men tend to prefer using Malay pronouns. The study also suggested a male-dominant distribution of the use of specific pronouns. Additionally, the younger groups of Malay speakers living in urban areas were shown to have more choices of address terms compared to an adult speaker.

\section{DATA AND METHODOLOGY}

This is a descriptive study that employs a qualitative approach. The data for this study were collected from two Malay dramas in the same genre. Ijab \& Qabul (The solemnization of marriage) and Tiga Hari Menanti Mati (Three Days Until Death) are realistic fiction dramas produced in 2015 with a duration of approximately 90 minutes each. These dramas portray authentic scenarios in the daily life of a Malay society in urban areas in Malaysia. The plot of the dramas centre on the love story between a husband and his wife who after several years of marriage were still childless. The husband was later confirmed by the doctor as infertile which led to the interference of the couple's parents and ultimately causing a rift in the couple's marriage. Given the range of interpersonal relationship and contexts depicted in the dramas, it was decided that these dramas were enough to provide sufficient data for analysis to answer the intended aims of this study.

Approximately forty-eight different address forms were identified and collected from the sample. The interactions occurred mainly at common places such as working and living spaces with the addition of a number of scenes at social establishments namely hospitals and restaurants. The interlocutors consist of family 
members, friends, colleagues, neighbours, doctor and patient, and etc. All the address forms identified in the dramas were recorded and analysed following the six categories of interpersonal relationships established by Kroger et al. (1984).

The process of analysing the data involved standard procedures. It started with the observation of the dramas as shown on television in order to gain an overall understanding of the story followed by a repeated observation of the recorded version on DVD. In the second observation, all the dialogues and interactions containing address forms were listed chronologically. The address terms were later structurally coded using common short forms namely; title alone (T), title with name (TN), first/short name (FSN), full name (FLN), kinship term (KT), kinship term with name (KTN) and, pronoun such as awak, kau, engkau (Pr). Unique address forms like hoi [hey] were classified as other expressions (OE).

\section{THEORY}

The data gathered for this study were analysed based on the format of classifying address terms that was established by Kroger et al. (1984). According to Brown (1965), an invariant norm of address refers to a tendency to address people of different social standing in a specific way which is reflected in the selection of address forms. The norm assumes that 'informal' forms of address are used by intimated equals and 'formal' forms by distant equals. An invariant norm of address defines a universal relationship between social power and intimacy and between inequality and equality in social relations (Dittrich, Johansen and Kulinskaya, 2011:1). Based on the invariant norms of address, Kroger et al. (1984) established a format of classifying the address terms and began to compare the usage of address forms among Korean, Greek and Chinese speakers.

In their study, Kroger et al. (1984) divided interpersonal relationships into six categories according to two sociolinguistic variables which are equality and intimacy. The six dyadic relationship are: (a) unequal intimate dyads: selfsuperordinate; (b) unequal intimate dyads: self-subordinate; (c) unequal nonintimate dyads: self-superordinate; (d) unequal non-intimate dyads: self-subordinate; (e) equal intimate dyads and; (f) equal non-intimate dyads.

In our study, the six dyadic categories are as illustrated in the following tables (Table 1 to Table 6) and the address forms used by the Malay speakers are noted with further descriptions denoting the context or location where the interaction occurred, and other important information such as the motivation of the speaker.

\section{RESULTS AND DISCUSSION}

The 48 different terms of address used in the selected dramas are grouped under six dyadic categories identified in the following six tables. There are four columns in each table representing the relationship between the addresser and addressee, the identity of the addresser and addressee, the type of address forms, and the description of the context in which the term of address were used. 
Table 1. Terms of address used in the equal and intimate dyad

\begin{tabular}{|c|c|c|c|}
\hline Relationship & $\begin{array}{l}\text { Addresser/ } \\
\text { Addressee }\end{array}$ & $\begin{array}{l}\text { Address } \\
\text { form }\end{array}$ & Description of the context \\
\hline \multirow[t]{10}{*}{ Friend } & \multirow[t]{4}{*}{$\begin{array}{l}\text { Zara/Wawa } \\
\text { (female/female) }\end{array}$} & $\operatorname{Pr}$ & $\begin{array}{l}\text { At the workplace: normally both Zara and } \\
\text { Wawa address each other with the pronoun } \\
\text { kau [you-inf.] and engkau [you - inf.]. Kau } \\
\text { is an abbreviation of Engkau. They are } \\
\text { female executives in their twenties and } \\
\text { colleagues working in the same office. } \\
\text { At home: both use the same pattern of } \\
\text { address term kau and engkau. } \\
\text { At the workplace: one day Wawa gets } \\
\text { angry and uses English pronoun 'you' when } \\
\text { addressing Zara. }\end{array}$ \\
\hline & & TN & $\begin{array}{l}\text { Wawa uses Cik Zara Nuraina [Miss Zara } \\
\text { Nuraina] when she is trying to explain } \\
\text { something to Zara. When Zara does not } \\
\text { show any interest, Wawa addresses her by } \\
\text { title and full name to get her attention and } \\
\text { also to add stress on the matter discussed. }\end{array}$ \\
\hline & & \multirow[t]{2}{*}{ FSN } & $\begin{array}{l}\text { At their boss's 'open house' event: Wawa is } \\
\text { speaking to Imran, and Zara calls Wawa by } \\
\text { her short name, } W a \text { to get her attention. }\end{array}$ \\
\hline & & & $\begin{array}{l}\text { At the hospital: Wawa calls her friend by } \\
\text { her short name, Zara when she is trying to } \\
\text { calm her friend down }\end{array}$ \\
\hline & Aida/Jamal & $\operatorname{Pr}$ & $\begin{array}{l}\text { At the workplace, Aida addresses her } \\
\text { colleague, Jamal, with the pronoun Hang } \\
\text { [you-inf.; dialect]. }\end{array}$ \\
\hline & \multirow[t]{4}{*}{$\begin{array}{l}\text { Sabri/Imran } \\
\text { (male/male) }\end{array}$} & \multirow[t]{2}{*}{$\operatorname{Pr}$} & $\begin{array}{l}\text { Sabri and Imran are colleagues and also } \\
\text { best friends. Both of them are using kau and } \\
\text { engkau when addressing each other during } \\
\text { interactions inside and outside the } \\
\text { workplace. }\end{array}$ \\
\hline & & & $\begin{array}{l}\text { When discussing work related matters, they } \\
\text { use the English pronoun 'you' to address } \\
\text { each other. }\end{array}$ \\
\hline & & \multirow[t]{2}{*}{$\mathrm{OE}$} & $\begin{array}{l}\text { In their interactions that are not related to } \\
\text { work, Sabri calls Imran using other } \\
\text { expression such as bro and hey. }\end{array}$ \\
\hline & & & $\begin{array}{l}\text { Sabri says "come on, man" when he is } \\
\text { asking for a favour from Imran. }\end{array}$ \\
\hline & $\begin{array}{l}\text { Jamal/Shahrul } \\
\text { (male/male) }\end{array}$ & $\mathrm{OE}$ & $\begin{array}{l}\text { At the workplace while discussing general } \\
\text { topics and joking around, Jamal suddenly } \\
\text { says something stupid that Shahrul } \\
\text { disagrees with. Jamal apologizes to his } \\
\text { friend by saying, "Ampunkan aku, }\end{array}$ \\
\hline
\end{tabular}




\begin{tabular}{|c|c|c|c|}
\hline Relationship & $\begin{array}{l}\text { Addresser/ } \\
\text { Addressee }\end{array}$ & $\begin{array}{l}\text { Address } \\
\text { form }\end{array}$ & Description of the context \\
\hline & & & $\begin{array}{l}\text { penunggu gua [I'm so sorry, cave } \\
\text { guardian]" and they laugh together. Both } \\
\text { are male and in their thirties. }\end{array}$ \\
\hline & $\begin{array}{l}\text { Wawa/Imran } \\
\text { (female/male) }\end{array}$ & $\operatorname{Pr}$ & $\begin{array}{l}\text { Wawa and Imran always use the pronoun } \\
\text { awak [you - inf.; polite] when addressing } \\
\text { each other inside and outside the } \\
\text { workplace. Sometimes they use the English } \\
\text { pronoun 'you' to express their feelings, i.e. } \\
\text { anger, disappointment, annoyance, etc. }\end{array}$ \\
\hline & $\begin{array}{l}\text { Aisyah/Emma } \\
\text { (female/female) }\end{array}$ & $\mathrm{OE}$ & $\begin{array}{l}\text { Emma is Aisyah's old neighbour. She } \\
\text { comes to visit Aisyah and they meet at } \\
\text { Aisyah's house. They are sitting in the } \\
\text { living room, talking about their daily life } \\
\text { and then Aisyah says, "Niii..suami kau tak } \\
\text { datang sekali? [Heyy...your husband did not } \\
\text { come along?]". Both are in their thirties and } \\
\text { married. Emma is a mother to a } 5 \text { year old } \\
\text { girl. }\end{array}$ \\
\hline \multirow[t]{7}{*}{$\begin{array}{l}\text { Significant } \\
\text { other }\end{array}$} & \multirow[t]{4}{*}{$\begin{array}{l}\text { Imran/Zara } \\
\text { (husband/wife) }\end{array}$} & $\operatorname{Pr}$ & $\begin{array}{l}\text { Most of the time they address each other } \\
\text { using the pronoun awak [you-inf.;polite] } \\
\text { either at the workplace, at Zara's home } \\
\text { when her parents are present or when they } \\
\text { are with other friends. When their } \\
\text { relationship develops into love that later led } \\
\text { to marriage, both sometimes use the } \\
\text { English pronoun 'you' in conversations at } \\
\text { the workplace and at home. }\end{array}$ \\
\hline & & FSN & $\begin{array}{l}\text { Imran calls his wife by her first name, Zara } \\
\text { when he apologizes to her in front of Zara's } \\
\text { parents. When they are alone or in private, } \\
\text { Imran calls Zara by her short name, } Z a \text {. }\end{array}$ \\
\hline & & FLN & $\begin{array}{l}\text { Imran calls his girlfriend by her full name, } \\
\text { Zara Nuraina, when he proposed. }\end{array}$ \\
\hline & & KT & $\begin{array}{l}\text { Zara always calls Imran abang [brother] } \\
\text { after they officially become husband and } \\
\text { wife. }\end{array}$ \\
\hline & $\begin{array}{l}\text { Aisyah/Shahrul } \\
\text { (wife/husband) }\end{array}$ & $\mathrm{OE}$ & $\begin{array}{l}\text { Shahrul is very sad when the doctor } \\
\text { confirmed that he is infertile. At the } \\
\text { hospital lobby, his wife says, "InsyaAllah, } \\
\text { sayang..[God willing, honey]" to give him } \\
\text { moral support. }\end{array}$ \\
\hline & \multirow[t]{2}{*}{$\begin{array}{l}\text { Wawa/Imran } \\
\text { (scandals) }\end{array}$} & $\operatorname{Pr}$ & $\begin{array}{l}\text { When Zara and Imran separated, Wawa } \\
\text { started getting closer to Imran and plans to } \\
\text { get married. They use the English pronoun } \\
\text { 'you' to address each other. }\end{array}$ \\
\hline & & FSN & $\begin{array}{l}\text { Wawa calls Imran by his short name, Im } \\
\text { when she wants something from him. }\end{array}$ \\
\hline
\end{tabular}




\begin{tabular}{|c|c|c|c|}
\hline Relationship & $\begin{array}{l}\text { Addresser/ } \\
\text { Addressee }\end{array}$ & $\begin{array}{l}\text { Address } \\
\text { form }\end{array}$ & Description of the context \\
\hline & \multirow[t]{3}{*}{$\begin{array}{l}\text { Imran's parents } \\
\text { (husband/wife) }\end{array}$} & KT & $\begin{array}{l}\text { Normally Imran's mother calls her husband } \\
\text { by kinship term bang/abang [brother]. }\end{array}$ \\
\hline & & $\operatorname{Pr}$ & $\begin{array}{l}\text { But when she is angry, she calls her } \\
\text { husband using the pronoun awak [you- } \\
\text { inf.;polite]. }\end{array}$ \\
\hline & & TN & $\begin{array}{l}\text { Imran's father calls his wife using title with } \\
\text { name, Cik Tom [Ma'am Tom], when they } \\
\text { are joking around and teasing each other } \\
\text { during the family's dinner. }\end{array}$ \\
\hline & $\begin{array}{l}\text { Johan/Lily } \\
\text { (husband/wife) }\end{array}$ & KT & $\begin{array}{l}\text { In the presence of their children, Lily calls } \\
\text { her husband by kinship term, Papa [Daddy] } \\
\text { and her husband addresses her as Mama } \\
\text { [Mom]. They are having a family dinner at } \\
\text { a restaurant. }\end{array}$ \\
\hline \multirow[t]{4}{*}{$\begin{array}{l}\text { "Co-parents- } \\
\text { in-law" }\end{array}$} & \multirow[t]{4}{*}{$\begin{array}{l}\text { Imran's parents } \\
\text { / Zara's parents }\end{array}$} & TN & $\begin{array}{l}\text { When Imran and Zara got married, their } \\
\text { parents became good friends. In addressing } \\
\text { one another, they use the address form title } \\
\text { with name: } \\
\text { - Imran's parents call Zara's mother } \\
\text { by title with name, Cik Jah [Ma'am } \\
\text { Jah] } \\
\text { - Zara's parents call Imran's mother } \\
\text { by title with name, Cik Tom } \\
\text { [Ma'am Tom] } \\
\text { - Imran's mother calls Zara's father } \\
\text { Encik Kamal [Mr. Kamal]. } \\
\text { - Zara's mother calls Imran's father } \\
\text { Encik Ismail [Mr. Ismail]. }\end{array}$ \\
\hline & & & $\begin{array}{l}\text { Normally Zara's father addresses Imran's } \\
\text { father using the pronoun awak. But at the } \\
\text { family reunion, he feels disappointed and } \\
\text { thinks that Imran's father has made a wrong } \\
\text { decision. He then starts addressing Imran's } \\
\text { father using the address form title with } \\
\text { name, Encik Ismail [Mr. Ismail] in their } \\
\text { conversations in the presence of their } \\
\text { children. }\end{array}$ \\
\hline & & $\operatorname{Pr}$ & $\begin{array}{l}\text { Imran's father and Zara's father use the } \\
\text { pronoun awak [you-inf.;polite] to address } \\
\text { each other. }\end{array}$ \\
\hline & & & $\begin{array}{l}\text { Both families are hoping to get a grandson. } \\
\text { Unfortunately, after } 5 \text { years of marriage, } \\
\text { their children are still without a child. At } \\
\text { the family reunion, Imran's father shows } \\
\text { his disappointment and suggested to his son }\end{array}$ \\
\hline
\end{tabular}




\begin{tabular}{|l|l|l|l|}
\hline Relationship & $\begin{array}{c}\text { Addresser/ } \\
\text { Addressee }\end{array}$ & $\begin{array}{c}\text { Address } \\
\text { form }\end{array}$ & \multicolumn{1}{c|}{ Description of the context } \\
\hline & & & $\begin{array}{l}\text { to marry another woman. In the presence of } \\
\text { their children, Zara's mother addresses } \\
\text { Imran's father using the pronoun awak } \\
\text { [you-inf.;polite]. }\end{array}$ \\
\hline
\end{tabular}

Table 1 indicates six different address terms used in the equal and intimate dyad such as friends, well-known colleagues, significant others and 'co-parents-in-law': pronoun (Pr), title with name (TN), first/short name (FSN), full name (FLN), kin term $(\mathrm{KT})$ and other expression $(\mathrm{OE})$.

From the data, it is found that social distance and situational context between the addresser and the addressee are important factors that influence the choice of terms of address in Malay speakers. For instance, among friends and well-known colleagues, FSN, pronoun kau or engkau [you-inf.; intimate] and other expression such as bro, penunggu gua [cave guardian], hoi [hey], and niii [hey] are used to address one another, regardless of age or social status (position held at the workplace). Additionally, dialectal address form hang [you-inf.] is also found between colleagues who are well acquainted. The dialectical pronoun hang is commonly used among speakers hailing from the Northern part of Malaysia.

Another special feature of the Malay speaker is shown in the use of kin terms between significant others. The wife normally addresses the husband using the kinship term, abang [brother] and the husband, on the other hand, uses FSN or other expressions such as sayang [sweetheart] when addressing their wife. However, the kin term abang [brother] to addresses the husband carries a different and special meaning, more like an affectionate term for husband. In another example stated in Table 1, the husband and his wife call each other by the term Papa and Mama in the presence of their children. The situational context also influences the type of address forms used between significant others. For example, the husband calls his wife using the term title plus name, Cik Tom [Ma'am Tom] when joking around and teasing each other during the family's dinner.

The 'co-parents-in-law' is still considered as non-relatives in the Malay culture, however they can be seen as a good friend. The address terms used among 'coparents-in-law' varies depending on several sociolinguistic factors such as personality, social status, and religious orientation, degree of respect, formality and intimacy. For example, Zara and Imran are husband and wife. In normal situations, their parents address each other using title plus name. For instance, Zara's mother calls Imran's parents by Cik Tom [Ma'am Tom] and Encik Ismail [Mr. Ismail]. However, an abnormal situational context changes the type of address form used and this is demonstrated when Zara's mother addresses Imran's father using the pronoun awak when she became upset and disagrees with the decision related to their children's marriage. 
Table 2. Terms of address used in the equal and non-intimate dyad

\begin{tabular}{|c|c|c|c|}
\hline Relationship & $\begin{array}{l}\text { Addresser/ } \\
\text { Addressee }\end{array}$ & $\begin{array}{l}\text { Address } \\
\text { form }\end{array}$ & Description of the context \\
\hline \multirow[t]{5}{*}{$\begin{array}{l}\text { Colleagues } \\
\text { (distant } \\
\text { relationship) }\end{array}$} & $\begin{array}{l}\text { Imran/Wawa } \\
\text { (male/female) }\end{array}$ & $\mathrm{OE}$ & $\begin{array}{l}\text { At their boss's 'open house' event: Imran } \\
\text { meets Wawa and Zara for the first time. He } \\
\text { calls Wawa hey - he doesn't know her name } \\
\text { and he wanted to ask Wawa about her friend, } \\
\text { Zara. Imran treats Wawa just like a friend. }\end{array}$ \\
\hline & \multirow[t]{4}{*}{$\begin{array}{l}\text { Wawa/Imran } \\
\text { (male/female) }\end{array}$} & $\operatorname{Pr}$ & $\begin{array}{l}\text { They normally use the pronoun awak [you- } \\
\text { inf.;polite] to address each other. Imran falls } \\
\text { in love with Zara and when trying to ask her } \\
\text { to go out to dinner with him, he addresses her } \\
\text { using the English pronoun 'you'. }\end{array}$ \\
\hline & & $\mathrm{TN}$ & $\begin{array}{l}\text { Zara feels like Imran is trying to flirt with her } \\
\text { hence with a cynical tone calls him using the } \\
\text { address form title with name Encik Imran } \\
\text { [Mr. Imran]. }\end{array}$ \\
\hline & & FSN & $\begin{array}{l}\text { Imran is continuously trying to get Zara's } \\
\text { attention. Zara gets really angry with Imran's } \\
\text { attitude and starts addressing him by his first } \\
\text { name, Imran. }\end{array}$ \\
\hline & & $\mathrm{OE}$ & $\begin{array}{l}\text { Using a cynical tone, Zara addresses Imran as } \\
\text { my dear when her colleague made the wrong } \\
\text { assumption about their relationship. Imran } \\
\text { says 'hey' to Zara when she is not listening to } \\
\text { him. }\end{array}$ \\
\hline \multirow[t]{5}{*}{ Strangers } & Imran/Kidnapper & $\mathrm{OE}$ & $\begin{array}{l}\text { At the car park, when Zara was almost } \\
\text { kidnapped, Imran yells bro to the kidnapper } \\
\text { and begs him not to do anything to Zara. }\end{array}$ \\
\hline & $\begin{array}{l}\text { Doctor/Patient's } \\
\text { spouse }\end{array}$ & $\mathrm{T}$ & $\begin{array}{l}\text { At the hospital, the male doctor explains } \\
\text { Zara's condition to Imran and uses the term } \\
\text { Encik [Mr.] when addressing Imran who is his } \\
\text { patient's spouse. } \\
\text { Another female doctor comes to Imran's } \\
\text { office and greets him using title with name, } \\
\text { Encik Imran [Mr. Imran]. The doctor knows } \\
\text { Imran, but Imran does not know the doctor. }\end{array}$ \\
\hline & $\begin{array}{l}\text { Patient's } \\
\text { spouse/Doctor }\end{array}$ & $\mathrm{T}$ & $\begin{array}{l}\text { Imran uses the title Doktor [Doctor] when he } \\
\text { is talking to Zara's Doctor at the hospital. } \\
\text { They do not know each other. }\end{array}$ \\
\hline & \multirow[t]{2}{*}{ Doctor/patient } & $\mathrm{T}$ & $\begin{array}{l}\text { In the consultation room, the patient have } \\
\text { never met the doctor and calls her by her } \\
\text { professional title, Doktor [doctor]. The patient } \\
\text { is in her twenties and suffers from memory } \\
\text { loss due to a car accident. }\end{array}$ \\
\hline & & $\operatorname{Pr}$ & $\begin{array}{l}\text { The doctor knows the patient and uses awak } \\
\text { [you-inf.;polite] in their conversation. They }\end{array}$ \\
\hline
\end{tabular}




\begin{tabular}{|l|l|l|l|}
\hline & & $\begin{array}{l}\text { are in the consultation room and both of them } \\
\text { are females. }\end{array}$ \\
\cline { 2 - 4 } & Sabri/Doctor & $\mathrm{T}$ & $\begin{array}{l}\text { Sabri meets Zara's doctor at Imran's office. } \\
\text { He tries to flirt with the doctor and calls her } \\
\text { using the title, Doc. They do not know each } \\
\text { other. }\end{array}$ \\
\hline
\end{tabular}

Table 2 shows forms of address in the equal and non-intimate dyad among unfamiliar colleagues and strangers. There were five address forms found in the two selected dramas: T, Pr, TN, FSN and OE.

Among unfamiliar colleagues or acquaintances, the title plus name and pronoun awak are commonly used in conversations at the workplace. A factor that influences the choice of address forms used towards this group is situational context. In the example between Imran and Zara, they were at the workplace and Zara feels that Imran is trying to flirt with her. To show her annoyance, she calls Imran in a cynical tone using the address form title plus name, Encik Imran.

When it comes to strangers, it can be seen that professional titles such as Doktor [Doctor] and general titles namely Encik [Mr.] are frequently used in conversations. In this example, social status plays an important role in determining the address forms used between interlocutors.

Table 3. Terms of address used in the unequal and intimate dyad (subordinate to superordinate)

\begin{tabular}{|c|c|c|c|}
\hline Relationship & $\begin{array}{l}\text { Addresser/ } \\
\text { Addressee }\end{array}$ & $\begin{array}{l}\text { Address } \\
\text { form }\end{array}$ & Description of the context \\
\hline \multirow[t]{2}{*}{ Family members } & \multirow[t]{2}{*}{ Daughter/Parents } & KT & $\begin{array}{l}\text { Zara always addresses her mother by } \\
\text { kinship term, Mak [mom]. But, due to } \\
\text { the car accident and loss of memory, } \\
\text { Zara does not recognize anyone } \\
\text { including her own parents. At the } \\
\text { hospital, in front of her father, } \\
\text { husband and parents-in-law, Zara } \\
\text { calls her mother by kinship term, } \\
\text { Kakak [sister] and asks about her } \\
\text { identity. Zara also calls her parents- } \\
\text { in-law using the kinship term ayah } \\
\text { [dad] and mak [mom]. } \\
\text { Aisyah always addresses her mother } \\
\text { as Mama [Mom]. } \\
\text { Amy always calls her mother, Ibu } \\
\text { [Mom]. }\end{array}$ \\
\hline & & $\operatorname{Pr}$ & $\begin{array}{l}\text { During a family dinner, Aisyah gives } \\
\text { a Mother's Day present to her } \\
\text { mother. Her mother was surprised } \\
\text { and Aisyah says, "You deserved it, }\end{array}$ \\
\hline
\end{tabular}




\begin{tabular}{|c|c|c|c|}
\hline & \multirow[b]{2}{*}{ Son/Parents } & \multirow[b]{2}{*}{ KT } & \multirow{2}{*}{$\begin{array}{l}\text { Mama". } \\
\text { Imran uses the kinship term, } \\
\text { ayah/yah [dad] and mak [mom] when } \\
\text { addressing his parents and parents-in- } \\
\text { law. }\end{array}$} \\
\hline & & & \\
\hline & $\begin{array}{l}\text { Children in- } \\
\text { law/Parents-in- } \\
\text { law }\end{array}$ & KT & $\begin{array}{l}\text { At their parents-in-law's house, } \\
\text { Imran and Zara both use the same } \\
\text { kinship term ayah [dad] and mak } \\
\text { [mom] to address their parents- in- } \\
\text { law. }\end{array}$ \\
\hline \multirow[t]{2}{*}{ Neighbours } & $\begin{array}{l}\text { Aisyah/old } \\
\text { neighbour }\end{array}$ & \multirow[t]{2}{*}{ KTN } & $\begin{array}{l}\text { Aisyah meets her old neighbour at } \\
\text { her parents' house and she greets her } \\
\text { using an English kinship term with } \\
\text { name, Auntie Rohaya. Aisyah is in } \\
\text { her twenties and the female old } \\
\text { neighbour is in her fifties. }\end{array}$ \\
\hline & $\begin{array}{l}\text { Neighbour/Zara's } \\
\text { mother }\end{array}$ & & $\begin{array}{l}\text { The young-adult male neighbour calls } \\
\text { Zara's mother by kinship term with } \\
\text { name, Mak Jah [Mother Jah] and tells } \\
\text { that her son in-law had an accident. } \\
\text { The neighbour is in his twenties. }\end{array}$ \\
\hline \multirow[t]{3}{*}{ Employee/Employer } & Employee/Nadia & KT & $\begin{array}{l}\text { Nadia is an owner of a coffee shop. } \\
\text { Her employee calls her using the } \\
\text { kinship term Kakak [sister] at the } \\
\text { workplace. Nadia is in her thirties and } \\
\text { the employee is in her twenties. }\end{array}$ \\
\hline & $\begin{array}{l}\text { Aida/Her } \\
\text { manager }\end{array}$ & $\mathrm{T}$ & $\begin{array}{l}\text { Aida is a personal assistant to the } \\
\text { Office Manager. At the workplace, } \\
\text { Aida always addresses her boss by } \\
\text { the title, Bos [Boss] in their } \\
\text { conversations. }\end{array}$ \\
\hline & Nurse / Doctor & $\mathrm{T}$ & $\begin{array}{l}\text { At the clinic, the nurse is asking the } \\
\text { doctor's permission. She addresses } \\
\text { her female superordinate by her } \\
\text { professional title, Doktor [Doctor]. }\end{array}$ \\
\hline Waitress/Customer & Female/Male & KT & $\begin{array}{l}\text { When Shahrul becomes a regular } \\
\text { customer at Nadia's coffee shop, the } \\
\text { female barista starts to address him } \\
\text { using the kinship term, abang } \\
\text { [brother]. }\end{array}$ \\
\hline
\end{tabular}

There were five different interlocutors found in the selected dramas that were classified in the unequal and intimate dyad (subordinate to superordinate) such as family members, old neighbour, employee-employer, neighbour and waitresscustomer. The data revealed four types of address form used between the addresser and the addressee: KT, KTN, Pr and T. 
Kin terms such as mak [mom], ayah [dad] are commonly used by children to address their parents. The parents-in-law are also addressed using kinship terms because in the Malay culture, in-laws are also considered as one's own family.

In Malaysia, however, the situational context influences the choice of address forms used by children to address their parents, particularly for those residing in urban areas. As mentioned previously, the Malay family in the urban areas tend to use English, rather than Malay as a medium of conversation. An example of this interaction occurred between Zara and her mother at their house. They spoke in English and Zara addressed her mother using the English pronoun 'you'.

Between neighbours, it is common in the Malay society for the younger to call an elder using kin term plus name. The data collected show two examples of the use of kin terms with name and the setting where the conversation occurred strongly influences the type of address term used. The first example occurs in the conversation between Zara and her old neighbour who came to visit her. Zara lives in the urban area in Kuala Lumpur. When she speaks to her old neighbour, she addresses her using the English kinship term with name, Auntie Rohaya. , The second instance occurs in the conversation between a young-adult and Zara's mother. The context where the conversation occurred is in the rural area. The addresser used a Malay kin term plus name, Mak Jah [Mom Jah], to address Zara's mother who is older than him.

Three other different address terms, specifically kin term and title, were also identified in conversations between the employee and the employer. The first instance is between Nadia, the owner of the coffee shop, and her female employee. At the workplace, her employee uses the kin term, kakak [sister], when addressing Nadia. Nadia is in her thirties and the female employee is in her twenties. The use of kin terms between employee and employer is common in Malaysia especially in a social workplace such as coffee shops and restaurants.

The use of title as an address form takes place twice with the first instance happening in a conversation between a personal assistant and her executive manager and the second instance between a nurse and a doctor. In the former situation, the personal assistant constantly addresses the executive manager, who is in her fifties, using the title boss throughout their conversations at the workplace. In the latter scenario, the nurse addresses the doctor using his professional title doktor [doctor] in their interactions in the consultation room. In both instances, the use of title as an address form is an indication of respect between a subordinate and their superior.

Table 4. Terms of address used in the unequal and intimate dyad (superordinate to subordinate)

\begin{tabular}{|l|c|c|l|}
\hline Relationship & $\begin{array}{c}\text { Addresser/ } \\
\text { Addressee }\end{array}$ & $\begin{array}{c}\text { Address } \\
\text { form }\end{array}$ & \multicolumn{1}{|c|}{ Description of the context } \\
\hline $\begin{array}{l}\text { Family } \\
\text { members }\end{array}$ & Parents/Children & FSN & $\begin{array}{l}\text { Zara's parents frequently call her by her first } \\
\text { name, Zara. The same applies in Imran's } \\
\text { family where his parents call him by his first } \\
\text { name, Imran and sometimes by his short }\end{array}$ \\
\hline
\end{tabular}

Indonesian Journal of EFL and Linguistics, 3(2), 2018 


\begin{tabular}{|c|c|c|c|}
\hline & & & name, Im. \\
\hline & & $\operatorname{Pr}$ & $\begin{array}{l}\text { Imran's father gets upset because his son does } \\
\text { not want to listen to his advice and he says, } \\
\text { "kau dengar sini Imran...[Imran, you listen } \\
\text { carefully...]". Most of the time, Imran's father } \\
\text { uses Engkau/kau [you-inf.;intimate] when } \\
\text { addressing his son. Imran's mother never uses } \\
\text { the pronoun kau/engkaulawak towards her } \\
\text { son. }\end{array}$ \\
\hline & & $\mathrm{OE}$ & $\begin{array}{l}\text { At the mosque, on the day Imran marries Zara, } \\
\text { Imran's father says hoi [hey] when Imran } \\
\text { entered the mosque and left his family behind. } \\
\text { At the hospital, Zara's mother is very happy } \\
\text { when Zara recovered from her coma. She calls } \\
\text { her daughter, sayang [sweetheart] and kissed } \\
\text { her. } \\
\text { Imran is struggling to survive from the car } \\
\text { accident. His father is extremely sad. He cries } \\
\text { and calls his son, anakku [my son] and holds } \\
\text { his hand but Imran dies at the end. }\end{array}$ \\
\hline & $\begin{array}{l}\text { Parents-in- } \\
\text { law/Children in- } \\
\text { law }\end{array}$ & FSN & $\begin{array}{l}\text { Imran's parents-in-law call him by his short } \\
\text { name, Im. Zara's parents-in-law call her by } \\
\text { her first name, Zara. }\end{array}$ \\
\hline & & $\operatorname{Pr}$ & $\begin{array}{l}\text { Shahrul's mother-in-law gets really upset } \\
\text { when she found out that her son-in-law is } \\
\text { infertile and is unable to give her a grandson. } \\
\text { At their house, she yells to her son-in-law and } \\
\text { says, "kau ingat kau siapa? [Who do you think } \\
\text { you are?]" to express her frustration. }\end{array}$ \\
\hline $\begin{array}{l}\text { Old } \\
\text { neighbour }\end{array}$ & $\begin{array}{l}\text { Aisyah/Emma's } \\
\text { daughter }\end{array}$ & $\mathrm{OE}$ & $\begin{array}{l}\text { Emma is a mother to a } 5 \text { year old girl. When } \\
\text { Aisyah meets Emma's daughter, she greets her } \\
\text { by saying, "Hello, darling..". }\end{array}$ \\
\hline $\begin{array}{l}\text { Employer } \\
\text { and } \\
\text { Employee }\end{array}$ & Doctor/Nurse & $\operatorname{Pr}$ & $\begin{array}{l}\text { At the clinic, in the presence of a patient, the } \\
\text { doctor uses the pronoun awak [you-inf.;polite] } \\
\text { when she speaks to the nurse. Both doctor and } \\
\text { nurse are females and in their thirties. }\end{array}$ \\
\hline
\end{tabular}

Table 4 indicates the address forms used in the unequal and intimate dyad (superordinate to subordinate). Among the interlocutors grouped in this dyad are family members, old neighbour and employer-employee. Three address forms were identified in the interactions between the interlocutors namely FSN, Pr and OE.

In interactions between family members, particularly between parents (including parents-in-law) and their children, again, situational context influences the choices of address forms. As revealed through the data, it is common for parents or parentsin-law to address their children using both first names and short names (FSN). However, when feelings or emotions is involved, the parents tend to use pronouns 
(Pr) rather than FSN. In the example between Imran and his father, the father's choice of address term changed spontaneously from FSN, Im to Pr, kau when he became upset because his son refuses to listen to his advice. Similarly in the conversation between parents-in-law and their children-in-law. In a normal situation, the parents-in-law addresses their children-in-law by FSN, however, the data shows how Imran's mother-in-law's choice of address term towards her son-in-law changed into the pronoun, kau when she became upset and disappointed in him.

Another address form used by the parents toward their children is categorised in other expression (OE). There were three forms found in both dramas and they are hoi [hey], sayang [sweetheart] and anakku [my son].

For interactions between employer and employee, only one form of address fitting this dyad was found. The use of the Pr, awak [you-inf.;polite] was identified during a conversation that occurred between a doctor and a nurse in her consultation room and in the presence of the patient. The doctor addressed the nurse by the pronoun awak when she requested her to assist the patient. This pronoun shows intimacy between the addresser and the addressee and reflects the politeness of the speaker.

The last example for this dyad is the use of intimate expressions that was uttered by the old neighbour towards a young girl. The addresser is much older than the addressee and in the Malay society, it is common for an older person to addresses a young child using intimate expressions such as darling or sweety.

Table 5. Terms of address used in the unequal and non-intimate dyad (subordinate to superordinate)

\begin{tabular}{|c|c|c|c|}
\hline Relationship & $\begin{array}{l}\text { Addresser/ } \\
\text { Addressee }\end{array}$ & $\begin{array}{l}\text { Address } \\
\text { form }\end{array}$ & Description of the context \\
\hline \multirow[t]{4}{*}{ Strangers } & \multirow[t]{3}{*}{ Sabri/Passer-by } & KT & $\begin{array}{l}\text { At the car park, Sabri greets a passer- } \\
\text { by using the address form pakcik } \\
\text { [uncle] because he does not know the } \\
\text { passer-by's name. Sabri is in his } \\
\text { twenties and the passer-by is an } \\
\text { elderly male citizen in his fifties. }\end{array}$ \\
\hline & & $\operatorname{Pr}$ & $\begin{array}{l}\text { When the male elderly passer-by } \\
\text { answered Sabri's question in English, } \\
\text { Sabri starts using the English pronoun } \\
\text { 'you' when addressing the passer-by } \\
\text { in their conversation at the car park. }\end{array}$ \\
\hline & & $\mathrm{T}$ & $\begin{array}{l}\text { When Imran was stabbed by the } \\
\text { kidnapper, Sabri calls out to an adult } \\
\text { male passer-by using the address term } \\
\text { Encik [Mr.] to ask for assistance to } \\
\text { send Imran to the hospital. The } \\
\text { passer-by is in his forties. }\end{array}$ \\
\hline & Amy/Shahrul & KT & $\begin{array}{l}\text { Amy is Nadia's daughter. She is } 9 \\
\text { years old. Shahrul comes to Nadia's } \\
\text { coffee shop and gets to know Amy. In } \\
\text { their conversation, Amy addresses }\end{array}$ \\
\hline
\end{tabular}




\begin{tabular}{|c|c|c|c|}
\hline & & & $\begin{array}{l}\text { Shahrul by the English kinship term, } \\
\text { uncle. Other times, she uses the Malay } \\
\text { kinship term Pakcik [Uncle]. They } \\
\text { still do not know each other. } \\
\text { After Shahrul became a regular } \\
\text { customer at her mother's coffee shop, } \\
\text { Amy and Shahrul formed a good } \\
\text { relationship. Shahrul asks Amy about } \\
\text { her father, and Amy says that her } \\
\text { father passed away due to a car } \\
\text { accident when they were in Japan. } \\
\text { Shahrul, wanting to be a father figure, } \\
\text { asks Amy to call him ayah [daddy]. }\end{array}$ \\
\hline & Shahrul/“Shaman” & KT & $\begin{array}{l}\text { After the doctor confirmed his } \\
\text { infertility, Shahrul talks to his friend, } \\
\text { Jamal. Being a good friend, Jamal } \\
\text { tries to help and takes Shahrul to see a } \\
\text { "shaman'. At the shaman's house, } \\
\text { they explained the problem and seek } \\
\text { the Shaman's help by saying, } \\
\text { "Harapnya Tok boleh tolong } \\
\text { [Hopefully grandfather can help us]". }\end{array}$ \\
\hline Waiter/Customer & Male/Male & $\mathrm{T}$ & $\begin{array}{l}\text { At the restaurant, the waiter greets } \\
\text { Shahrul by title, Encik [Mr.], when he } \\
\text { comes to take an order. }\end{array}$ \\
\hline Waitress/Customer & Female/Male & $\mathrm{T}$ & $\begin{array}{l}\text { At the coffee shop, the female barista } \\
\text { serves coffee to the customer and } \\
\text { says, "Sir, if you want anything else, } \\
\text { please let me know". }\end{array}$ \\
\hline
\end{tabular}

Table 5 lists the address forms used in the two selected family dramas in the unequal and non-intimate dyad (subordinate to superordinate) that occurred between strangers or when the waiter/waitress addressed their costumer. As listed in the table, there were three different types of address forms; kinship term, title and pronoun used by the subordinate when addressing the superordinate.

In this category, it is evident that apart from the context where the conversation occurs, age also plays an important role in determining the choice of address terms. In the conversation between Shahrul and 'shaman', Shahrul, who is in his thirties calls the 'shaman', who is in his sixties, using the kinship term, tok [grandfather], despite the fact that both the addresser and addressee have never previously met each other or are not biologically related. The same situation occurred in the conversation between Sabri who is in his thirties and the passer-by who is in his fifties. The conversation between Sabri, a male adult citizen with the passer-by, the male senior citizen, was carried out in English. However, Sabri calls the passer-by using the Malay kinship term, pakcik [uncle]. 
The use of kinship term by the addresser towards someone elder, even though they are not related, is common in the Malay society. This is illustrated in the interactions between Amy, a 9 years old girl, and Shahrul. They first met at the café owned by Amy's mother. They do not know each other and Amy addresses Shahrul, who is much older than she is by the kinship term, pakcik [uncle]. When Amy and Shahrul became closer, Amy switched the address term she used towards Shahrul from pakcik [uncle] to ayah [daddy]. Kinship terms are used to show politeness between the addresser and addressee and reflect good etiquette that is highly valued in the Malay culture (Raminah Hj Sabran and Rahim Syam 1984:237).

The analysis also shows the use of the address form title occurring in conversations between a subordinate and superordinate. In this example, gender appears to influence the choice of address forms. At the coffee shop, the waiter addresses the male customer by the Malay title, Encik [Mr.] when he takes his order. However, his colleague, a female barista, speaks in English and uses an English general title, 'Sir' when addressing the same customer. This situation supports the intuitive judgements proposed by Normala Othman (2006) who suggested that Malay women tend to use English pronouns regardless of age and profession.

Table 6. Terms of address used in the unequal and non-intimate dyad (superordinate to subordinate)

\begin{tabular}{|l|l|l|l|}
\hline Relationship & $\begin{array}{c}\text { Addresser/ } \\
\text { Addressee }\end{array}$ & $\begin{array}{c}\text { Address } \\
\text { form }\end{array}$ & \multicolumn{1}{|c|}{ Description of the context } \\
\hline Strangers & Passer-by/Sabri & Pr & $\begin{array}{l}\text { The male elderly passer-by uses the English } \\
\text { pronoun 'you when addressing Sabri. The } \\
\text { passer-by is in his fifties and Sabri is in his } \\
\text { thirties. After Sabri introduced himself, the } \\
\text { passer-by uses the English pronoun 'you' } \\
\text { and also calls him by his first name, Sabri, in } \\
\text { their conversations. }\end{array}$ \\
\cline { 2 - 3 } & 'Shaman'Shahrul & $\operatorname{Pr}$ & $\begin{array}{l}\text { At the shaman's house, the 'shaman' spells } \\
\text { the water and gives it to Shahrul and says, } \\
\text { "Berikan air ini pada isterimu..[Give this } \\
\text { water to your wife..]". The 'shaman' is in his } \\
\text { sixties. }\end{array}$ \\
\hline
\end{tabular}

As shown in Table 6, only one relationship, which is between strangers, and three address forms - the English pronoun 'you', -mu [you-inf.] and first name - were found in the unequal and non-intimate dyad.

The special feature of Malay language is revealed in the use of kinship terms. Malay language is found to be very dependent on family relations and this is especially notable in reverse addressing or the use of kinship terms for non-relatives. The conversation between the passer-by and Sabri happened at a public space and were carried out in English. Sabri is in his thirties and the passer-by is a male senior citizen in his fifties. This situation is significant because the addresser and addressee are exposed to urban life where English is widely spoken (Normala, 2006). However, with regard to the choices of address terms between strangers in the 
Malay culture, it is found that age is an important factor that influences their choices. The data shows that the addresser (the senior citizen) addresses the younger addressee (Sabri) using the English pronoun 'you' and sometimes calls him by his first name. Alternately, Sabri only uses the term pakcik [uncle] in their conversations to shows politeness.

The pronoun $-m u$ [you-inf.] appeared in the conversation between the 'shaman' and Shahrul. This pronoun is an abbreviation of kamu which refers to the person being addressed. The use of $-m u$ indirectly reduces formality and increases the intimacy between interlocutors.

\section{CONCLUSION}

The data from the two selected family dramas shows that interpersonal relationship and context are two of the important factors that determine the choices of address terms among Malay speakers. In other words, the employment of a proper address form is affected by sociolinguistic elements such as age, gender, personality, social status, social distance, degree of respect, familiarity, family relationship and intimacy between the addresser and the addressee.

The results of this study will benefit the linguistic communities in particular Malay language learners by providing an in-depth understanding of the current usage of Malay second person address terms. As globalization mandates for skills in intercultural communications to enhance business negotiations or academic endeavours, intercultural knowledge that includes knowledge of appropriate address terms and sociocultural factors influencing the choice of address terms is essential to avoid misunderstandings during interactions.

\section{REFERENCES}

Brown, Roger. (1965). Social Psychology. Chicago: Free Press.

Brown, Penelope \& Levinson, Stephen. (1987). Politeness: Some Universals in Language Usage. Cambridge: Cambridge University Press.

Chao, Yuenren. (1956). Chinese Terms of Address. Language, 1.217-241.

Dittrich, Winand H., Johansen, Thomas \& Kulinskaya, Elena. (2011). Norms and Situational Rules of Address in English and Orwegian Speakers. Journal of Pragmatics. Doi: 10.1016/j.pragma.2011.09.006

Gan, Aries D., David, Maya K. \& Dumanig, Francisco P. (2015). Politeness Strategies and Address Forms used by Filipino Domestic Helpers in Addressing their Malaysian Employers. Language in India, 15(1): 46-73.

Gaudart, Hyacinth. (1999). The Trouble with Names in Asia. Singapore: SNP Editions.

Hayakawa, Samuel I. (1978). Language in Thought and Action. Orlando, FL: Harcourt Brace Jovanovich.

Hei, Kuang C., David, Maya K., Kia, Lau S. \& Soo, Ang P. (2011). Opening and Closing in front Counter Transactions of Malaysian Government Hospitals. 
The Journal of the South East Asia Research Centre for Communication and Humanities, 3.13-30.

Kroger, Rolf O, Wood, Linda \& Kim, Uichol. (1984). Are the Rules of Address Universal? III: Comparisons of Chinese, Greek and Korean Usage. Journal of Cross-Cultural Psychology, 3.273-284.

Normala Othman. (2006). Current Trends in Pronoun Usage among Malay Speakers. Paper presented at Tenth International Conference on Austronesian Linguistics. 17-20 January 2006. Puerto Princesa City, Palawan, Philippines.

Parkinson, Dilworth B. (1985). Constructing the Social Context of Communication: Terms of Address in Egyptian Arabic. New York: Mouton de Gruyter.

Qin, Xizhen. (2008). Choices in terms of address: A sociolinguistic study of Chinese and American English practices. Proceeding of the $20^{\text {th }}$ North American Conference on Chinese Linguistics (NACCL-20), Columbus, Ohio: The Ohio State University.

Raminah Hj. Sabran \& Rahim Syam. (1984). Kajian bahasa untuk pelatih maktab perguruan [A study of language for trainers in teacher institutions]. Petaling Jaya: Fajar Bakti Sdn. Bhd.

Wood, Linda A. \& Kroger, Roger. (1991). Politeness and Forms of Address. Journal of Language and Social Psychology, 3.145-168. 